Research Article Animal Genetics

\title{
Haplotypes traceability and genetic variability of the breeding population of pacu (Piaractus mesopotamicus) revealed by mitochondrial DNA
}

\author{
Milena V. de Freitas ${ }^{1}\left(\mathbb{D}\right.$, Raquel B. Ariede ${ }^{1}(\mathbb{D})$ Milene E. Hata $^{1}\left(\mathbb{D}\right.$, Vito A. Mastrochirico-Filho ${ }^{1}$ (D), \\ Felipe Del Pazo ${ }^{2}$ (D), Gabriela V. Villanova² (1), Fernando F. Mendonça ${ }^{3}$ (1), Fábio Porto-Foresti ${ }^{4}$ (D) \\ and Diogo T. Hashimoto ${ }^{1 *}$ (10 \\ ${ }^{I}$ Universidade Estadual Paulista "Júlio de Mesquita Filho" (UNESP), Centro de Aquicultura, Jaboticabal, \\ SP, Brazil. \\ ${ }^{2}$ Universidad Nacional de Rosario, Facultad de Ciencias Bioquímicas y Farmacéuticas - Ministerio \\ de Ciencia, Tecnología e Innovación productiva de Santa Fe, Centro Cientifico y Tecnológico Acuario \\ del Río Paraná, Rosario, Santa Fe, Argentina. \\ ${ }^{3}$ Universidade Federal de São Paulo (UNIFESP), Instituto do Mar, Santos, SP, Brazil. \\ ${ }^{4}$ Universidade Estadual Paulista "Júlio de Mesquita Filho" (UNESP), Faculdade de Ciências,, Bauru, \\ SP, Brazil.
}

\begin{abstract}
The main objective of this study was to estimate the genetic diversity levels and haplotype traceability in pacu Piaractus mesopotamicus from the breeding program located in Brazil by analyses of the mitochondrial DNA control region (mtDNA). Moreover, broodstocks from eight commercial fish farms were used for comparative evaluation, four from Brazil (Br1-Br4) and four from Argentina (Ar1-Ar4). The descriptive results revealed 47 polymorphic sites and 51 mutations, which evidenced 34 haplotypes. Ten haplotypes were shared among fish farms and 24 were exclusive. The nucleotide diversity $(\pi)$ ranged from 0.00031 to 0.01462 and haplotype diversity $(\mathrm{Hd})$ from 0.125 to 0.868 . The analysis of molecular variance (AMOVA) indicated high structure present in the analyzed stocks $\left(F_{\mathrm{ST}}=0.13356\right.$ and $\left.\Phi_{\mathrm{ST}}=0.52707\right)$. The genetic diversity was high in most of the commercial broodstocks, especially those from Brazil. We observed seven haplotypes in the genetic breeding population, of which four were exclusive and three shared among the commercial fish farms. The genetic diversity was moderate $(\pi=0.00265$ and $\mathrm{Hd}=0.424)$ and considered appropriated for this breeding population of pacu. Our results provide support for the genetic diversity maintenance and mtDNA traceability of pacu commercial broodstocks.
\end{abstract}

Keywords: Control-region, genetic breeding, aquaculture.

Received: July 16, 2020; Accepted: January 20, 2021.

\section{Introduction}

The species Piaractus mesopotamicus, popularly known as pacu, is a Serrasalmidae fish of commercial importance distributed in the Paraná, Paraguay, and Uruguay River basins, mainly in the Pantanal plains (Petrere Jr, 1989). Pacu is one of the main farmed fish of the South American aquaculture, occupying the 6th position of production in Brazil, together with its hybrid patinga (obtained by crossing P. mesopotamicus and Piaractus brachypomus), with an estimated annual production of 13,276 tons (IBGE, 2015). In addition, pacu has a representative production in Argentina, where it is the main farmed fish produced $(52.6 \%$ of the total production, 2,119 tons) (Schenone et al., 2011; Panné Huidobro, 2015); and in Asian countries (China, Myanmar, Thailand and Vietnam) (Flores Nava, 2007; Honglang, 2007; FAO, 2010; Lin et al., 2015; Valladão et al., 2018).

Send correspondence to: Diogo T. Hashimoto. São Paulo State University (Unesp), Aquaculture Center of Unesp, Via de Acesso Prof. Paulo Donato Castellane, s/n, 14884-900 Jaboticabal, SP, Brazil. E-mail: diogo.hashimoto@unesp.br.
Currently, major breeding programs in aquaculture have been performed using a family scheme, which can lead to the selection of siblings (Gjedrem and Baranski, 2010). However, the formation of inbred families and the use of breeding units with low genetic variability result in loss of genetic potential and inbreeding risks (Melo et al., 2006; Charlesworth and Willis, 2009). In rainbow trout (Oncorhynchus mykiss), the different degrees of inbreeding depression significantly affected the percentage of hatching, fecundity and larval survival, as well as generating individuals with morphological deformities (Yosefian and Nejati, 2008). Although the characterization of genetic variability is a fundamental tool when initiating genetic breeding programs (Mastrochirico-Filho et al., 2019a), few studies have been developed in this scope.

Recently, genetic diversity was assessed by nuclear markers SNPs (single-nucleotide polymorphisms) and microsatellites in different fish farms from Brazil for a prebreeding program in Piaractus mesopotamicus (MastrochiricoFilho et al., 2019a). These previous results have evidenced genetic variability and structure at low level in pacu farmed stocks, including fish profiles with risks of inbreeding. This information was exploited for the creation of the breeding 
population to select superior genotypes related to growth performance and disease resistance in pacu (MastrochiricoFilho et al., 2019b; Freitas et al., 2020). Nowadays, supplementary studies are still required to follow up the level of genetic diversity of this breeding population (MastrochiricoFilho et al., 2019b; Freitas et al., 2020) in pacu, particularly using the control region (CR) of the mitochondrial DNA (mtDNA) that has relatively lower mutation fixation rate than microsatellites and, therefore, is appropriated to capture genetic differences in older (non-contemporary) events and to assess traceability of fish products resulting from genetic improvement (Aquadro and Greenberg, 1983; Meyer, 1993; Brown et al., 1993).

The main objectives of this study were: 1) to assess the genetic diversity by mtDNA in the breeding population of pacu from Caunesp (Aquaculture Center of the São Paulo State University, Brazil); 2) to identify unique haplotypes in this breeding population for traceability of products resultant from genetic improvement by mtDNA; 3 ) to compare farmed stocks from different Brazilian and Argentinian commercial fish farms by mtDNA in order to detect non-contemporary genetic differences of founder stocks and to understand the haplotype diversity and distribution between these countries.

\section{Material and Methods}

\section{Experimental populations}

Pacu individuals Piaractus mesopotamicus from the breeding nucleus belonging to the Caunesp (Aquaculture Center, São Paulo State University, Jaboticabal, Brazil) were used for the genetic analysis. These breeders are resulting from the base population established with purposes of genetic selection for growth performance and disease resistance in pacu (Mastrochirico-Filho et al., 2019b; Freitas et al., 2020). In addition, samples from eight different commercial broodstocks from fish farms in Brazil and Argentina were also collected (number of individuals and fish farms are shown in Table 1). The commercial identity and localization of the fish farms were kept confidential. Animals were individually tagged with transponders (passive integrated transponder tags - pit- tags, model full-duplex FDX-B, $134.2 \mathrm{kHz}$ ) and kept alive for subsequent management. Fish farms were mostly set up between the 1980s and 1990s. There are no records of selective mating in the commercial broodstocks.

Fin samples were collected from each fish under benzocaine solution (200 mg $\mathrm{mb}^{\mathrm{L}-1}$ ) (Sigma, St. Louis, USA) anesthesia and all efforts were made to minimize suffering. Fin samples were stored in $95 \%$ ethanol at $-20^{\circ} \mathrm{C}$.

\section{Amplification of the control region and sequencing}

DNA extraction was carried out using the Wizard Genomic DNA Purification Kit (Promega). DNA integrity was evaluated on $1 \%$ agarose gel and its purity was assessed using a NanoDrop One spectrophotometer (Thermo Fisher, Madison, USA). The DNA concentration was quantified using the Qubit dsDNA BR Assay kit (Life Technologies, Oregon, USA) and measured in a Qubit 3.0 Fluorometer (Invitrogen, Kuala Lumpur, Malaysia).

Genetic diversity was assessed through the partial sequencing of the mitochondrial DNA control region (D-loop). The primers PM01 (5'GATCCCAGTACATTATATGTAT3') and PM02 (5'CCTTGTTAATCATTACRCTGA3') were designed using the software Geneious V.7.1.3, using the mitochondrial genome of P. mesopotamicus (NC_024940) as reference. PCR assays were performed at a final volume of $12 \mu \mathrm{l}$ : 1X Taq polymerase buffer; $1.5 \mathrm{mM} \mathrm{MgCl}^{2} ; 100 \mu \mathrm{M}$ of each dNTP; $0.1 \mu \mathrm{M}$ of each primer; $10-50 \mathrm{ng}$ of genomic DNA and $0.5 \mathrm{U}$ of Taq polymerase (Invitrogen). The following amplification cycle was used: denaturation $94^{\circ} \mathrm{C}$ for $3 \mathrm{~min}, 35$ cycles of denaturation at $94{ }^{\circ} \mathrm{C}$ for $1 \mathrm{~min}$; annealing at $62^{\circ} \mathrm{C}$ for 45 , extension to $72^{\circ} \mathrm{C}$ for $1 \mathrm{~min}$, and a final extension at $72{ }^{\circ} \mathrm{C}$ for $10 \mathrm{~min}$. PCR assays were performed on the ProFlex TM PCR System (Life technologies) and the final product checked in $1.5 \%$ agarose gel.

PCR products were cleaned with EXO-SAP Kit (USB $\AA$ ExoSAP-IT ${ }^{\circledR}$ PCR Product Cleanup) and then underwent PCR sequencing, using BigDYE, Terminator Cycle Sequencing Kit version 3, 1 (Applied Biosystems, Inc.). The sequencing was performed in the Center of Biological Resources and Genomic Biology (CREBIO), in UNESP - Jaboticabal, Brazil, using the ABI 3730 XL DNA Analyzer (Applied Biosystems).

Table 1 - Genetic parameters of mtDNA diversity in farmed individuals of $P$. mesopotamicus.

\begin{tabular}{|c|c|c|c|c|c|c|}
\hline Origin & Fish Farms & $\mathrm{N}$ & $\mathrm{S}$ & $\mathrm{h}$ & $\mathrm{Hd}$ & $\pi$ \\
\hline \multirow[t]{4}{*}{ Argentina } & Ar1 & 16 & 1 & 2 & 0.233 & 0.00058 \\
\hline & Ar2 & 14 & 6 & 8 & 0.868 & 0.00640 \\
\hline & Ar3 & 16 & 1 & 2 & 0.125 & 0.00031 \\
\hline & Ar4 & 14 & 27 & 8 & 0.824 & 0.01462 \\
\hline \multirow[t]{6}{*}{ Brazil } & $\mathrm{Br} 1$ & 14 & 4 & 3 & 0.385 & 0.00198 \\
\hline & $\mathrm{Br} 2$ & 16 & 15 & 9 & 0.858 & 0.00917 \\
\hline & $\mathrm{Br} 3$ & 19 & 17 & 7 & 0.749 & 0.00671 \\
\hline & $\mathrm{Br} 4$ & 18 & 10 & 5 & 0.660 & 0.00894 \\
\hline & CAUNESP & 41 & 13 & 7 & 0.424 & 0.00265 \\
\hline & All & 168 & 47 & 34 & 0.656 & 0.00163 \\
\hline
\end{tabular}

$\mathrm{N}=$ number of individuals, $\mathrm{S}=$ polymorphic sites, $\mathrm{h}=$ haplotypes, $\mathrm{Hd}=$ Haplotypic diversity, $\pi=$ nucleotide diversity 


\section{Statistical Analysis}

The assembled sequences were analyzed manually using the program CLUSTALW (Thompson et al., 1994), included in the program Bioedit (Hall, 1999). The nucleotide compositions, sequence diversity, number of polymorphic areas, and haplotype diversity were calculated using the software DNAsp v.5 (Librado and Rozas, 2009). The Analysis of Molecular Variance (AMOVA) (Excoffier et al., 1992) was conducted to test the genetic heterogeneity between mtDNA haplotypes using ARLEQUIN version 3.01 (Excoffier et al., 2007), which uses Wright's F-statistics (1951, 1965). Haplotype network was estimated by Software Network v 4.6.1.0.

\section{Results}

The results revealed 47 polymorphic sites from approximately 400 sequenced base pairs (bp), characterizing 34 haplotypes (GenBank accession numbers MW287387 MW287554). Among the haplotypes, 10 were shared among broodstocks, of which two ( $\mathrm{H} 1$ and $\mathrm{H} 2)$ were shared between samples from Brazilian and Argentinian fish farms. In addition, 24 unique haplotypes were detected, of which 11 were in Argentina, 9 were in Brazil, and 4 were exclusive from the base population of the breeding nucleus (Table 2). The most representative haplotype was $\mathrm{H} 1$, which was distributed in all fish farms. The percentage of bases among the haplotypes

Table 2 - mtDNA haplotypes distribution among fish farms (Ar and Br) and the breeding nucleus (CAUNESP).

\begin{tabular}{|c|c|c|c|c|c|c|c|c|c|c|c|}
\hline $\mathrm{h}$ & Ar1 & Ar2 & Ar3 & Ar4 & $\mathrm{Br} 1$ & $\mathrm{Br} 2$ & $\mathrm{Br} 3$ & $\mathrm{Br} 4$ & CAUNESP & All & $\%$ \\
\hline h1 & 14 & 4 & 6 & 15 & 8 & 11 & 6 & 1 & 12 & 77 & 51.6 \\
\hline h2 & 2 & 1 & & 1 & & 2 & 2 & & & 8 & 5.3 \\
\hline h3 & & 4 & & & & & & & & 4 & 2.6 \\
\hline h4 & & 1 & & & & & & & & 1 & 0.6 \\
\hline h5 & & 1 & & & & & & & & 1 & 0.6 \\
\hline h6 & & 1 & & & & & & & & 1 & 0.6 \\
\hline h7 & & 1 & & & & & & & & 1 & 0.6 \\
\hline h8 & & 1 & & & & & & & & 1 & 0.6 \\
\hline h9 & & & & & & 1 & & & & 1 & 0.6 \\
\hline h10 & & & & & 6 & & 1 & 10 & 4 & 21 & 14.0 \\
\hline h11 & & & & & & & 1 & & & 1 & 0.6 \\
\hline h12 & & & & & & & 2 & & & 2 & 1.3 \\
\hline h13 & & & & & & & 1 & & & 1 & 0.6 \\
\hline h14 & & & & & & & 1 & & & 1 & 0.6 \\
\hline h15 & & & & & 1 & & 1 & & & 2 & 1.3 \\
\hline h16 & & & & & & & 1 & & & 1 & 0.6 \\
\hline h17 & & & & & 1 & & & 4 & & 5 & 3.3 \\
\hline h18 & & & & & 1 & & & & & 1 & 0.6 \\
\hline h19 & & & & & 1 & & & & & 1 & 0.6 \\
\hline h20 & & & & & 1 & & & & & 1 & 0.6 \\
\hline h21 & & & & & & & & 2 & & 2 & 1.3 \\
\hline h22 & & & & & & & & 1 & & 1 & 0.6 \\
\hline h23 & & & 2 & & & & & & & 2 & 1.3 \\
\hline h24 & & & 1 & & & & & & & 1 & 0.6 \\
\hline h25 & & & 1 & & & & & & & 1 & 0.6 \\
\hline h26 & & & 1 & & & & & & & 1 & 0.6 \\
\hline h27 & & & 1 & & & & & & & 1 & 0.6 \\
\hline h28 & & & 1 & & & & & & & 1 & 0.6 \\
\hline h29 & & & 1 & & & & & & & 1 & 0.6 \\
\hline h30 & & & & & & & & & 1 & 1 & 0.6 \\
\hline h31 & & & & & & & & & 2 & 2 & 1.3 \\
\hline h32 & & & & & & & & & 1 & 1 & 0.6 \\
\hline h33 & & & & & & & & & 1 & 1 & 0.6 \\
\hline h34 & & & & & & & & & 1 & 1 & 0.6 \\
\hline
\end{tabular}


corresponded to $28.4 \%$ Adenine (A), 33.4\% Thymine (T), $22.1 \%$ Cytosine $(\mathrm{C})$ and $16.1 \%$ Guanine $(\mathrm{G})$.

The nucleotide $(\pi)$ and haplotypic $(\mathrm{Hd})$ diversity demonstrated moderate values in the base population of the breeding nucleus ( $\pi=0.00265$ and $\mathrm{Hd}=0.424)$ (Table 1$)$ and indicated two distinct patterns of genetic variability in the commercial fish farms, with stocks with high and low genetic diversity. The highest haplotype diversity was found in Ar2 $(\mathrm{Hd}=0.868)$, and the lowest diversity in $\mathrm{Ar} 3(\mathrm{Hd}=0.125)$. The nucleotide diversity was higher in Ar4 $(\pi=0.01451)$ and lower in $\operatorname{Ar} 3(\pi=0.00031)$. In general, the genetic diversity was high (Global/Total Hd $=0.656$ and $\pi=0.00163$ ). The genetic variability was moderate $(\pi=0.00265$ and $\mathrm{Hd}=0.424)$ for this breeding population of pacu.

For the calculation of molecular variance (AMOVA) (Table 3), the populations were clustered according to the origin of the fish farm (Argentina and Brazil). The highest genetic variation was found within the populations. The $F_{\mathrm{ST}}$ index indicated a high genetic structure among the populations $\left(F_{\mathrm{ST}}=0.13356\right)$, similarly to the $\Phi_{\mathrm{ST}}$ index $(0.52707, \mathrm{p}<0.05)$. The pairwise $F_{\mathrm{ST}}$ matrix also revealed high genetic structure between the broodstocks (Table 4), particularly comparing the broodstocks from Argentina.

The haplotype network (Figure 1) revealed the H1 haplotype as ancestral, and the consequent establishment of the other haplotypes. There was no evident distribution pattern of the haplotypes between the fish farms from Brazil and Argentina, and only the $\mathrm{H} 1$ and $\mathrm{H} 2$ haplotypes were present in the fish farms from both countries.

\section{Discussion}

Inbreeding depression is one of the factors that most affects individuals due to the classical (phenotype-based) selection method in the breeding nucleus. The main genetic problems arising from the inappropriate use of fish in breeding programs can be reduced and even avoided using the genetic profile of the individuals and proper genetic management practices, similarly as it was performed to compose the base population of the breeding nucleus (CAUNESP) in pacu (Mastrochirico-Filho et al., 2019b; Freitas et al., 2020). This was supported by the analysis of the present study, which revealed a moderate pattern of genetic diversity in this breeding population. Moreover, the mtDNA results can be also applied to maximize the genetic variability in the subsequent generations of the selection process in pacu, considering the composition of different haplotypes during the selection steps. The data herein obtained also provides exclusive markers for the genetic traceability of the products resulting from the genetic improvement process, especially the unique haplotypes detected in this initial base population, which will later allow identifying their progenies as products from selection process. However, studies approaching additional samples and fish farms will be still necessary to corroborate the practical and reliable applicability of these haplotypes for traceability analysis.

Our results indicated high values of genetic variability in most of the commercial broodstocks of farmed pacu, similarly to the genetic pattern of wild populations also using mtDNA (Iervolino et al., 2010), which represents the potential use of these stocks in genetic selection programs. However, three broodstocks registered low variability rates (Ar1, Ar3 and $\mathrm{Br} 1$ ), similar to those obtained in others farmed broodstocks analyzed by SNP and microsatellite markers (MastrochiricoFilho et al., 2019a), which detected low values of allele number and heterozygosity. Low genetic diversity may represent populations with genetic drift events due to low effective population sizes and recent bottleneck effects/founder events (Mastrochirico-Filho et al., 2019a); therefore, the fish farms

Table 3 - Analysis of molecular variance (AMOVA)

\begin{tabular}{lccc}
\hline & \multicolumn{3}{c}{ AMOVA } \\
\hline & Variance Components & percentage of variation $(\%)$ & -2.16 \\
Among groups & -0.02591 & 15.51 & 0.13356 \\
Among populations within groups & 0.18649 & 86.64 & $* F_{\mathrm{ST}}$ \\
Within populations & 1.04173 & 0.52707 & \\
\hline
\end{tabular}

*Significant $\mathrm{p}$ values $\mathrm{p}<0.05$

Table 4 - Differentiation index $\left(F_{\mathrm{ST}}\right)$ between pairs of broodstocks of fish farms from Argentina, Brazil, and the breeding nucleus (CAUNESP) of Piaractus mesopotamicus.

\begin{tabular}{|c|c|c|c|c|c|c|c|c|c|}
\hline & Ar1 & Ar2 & Ar3 & Ar4 & $\mathrm{Br} 1$ & $\mathrm{Br} 2$ & $\mathrm{Br} 3$ & $\mathrm{Br} 4$ & CAUNESP \\
\hline Ar1 & & 0.31846 & -0.04242 & 0.15974 & -0.02008 & 0.08905 & 0.10289 & 0.30470 & 0.02456 \\
\hline Ar2 & & & 0.33508 & 0.08766 & 0.26022 & 0.06663 & 0.19733 & 0.22388 & 0.31749 \\
\hline Ar3 & & & & 0.16055 & 0.02088 & 0.09789 & 0.10117 & 0.30803 & 0.01479 \\
\hline Ar4 & & & & & 0.13960 & 0.01856 & 0.10984 & 0.11313 & 0.20089 \\
\hline $\mathrm{Br} 1$ & & & & & & 0.05729 & 0.08362 & 0.27399 & 0.05071 \\
\hline $\mathrm{Br} 2$ & & & & & & & 0.01570 & 0.05811 & 0.08390 \\
\hline $\mathrm{Br} 3$ & & & & & & & & 0.06433 & 0.03517 \\
\hline $\mathrm{Br} 4$ & & & & & & & & & 0.25143 \\
\hline CAUNESP & & & & & & & & & \\
\hline
\end{tabular}

Pairwise $\mathrm{F}_{\mathrm{st}}$ numbers are above de diagonal line. and the significant of the p-values are in bold. 


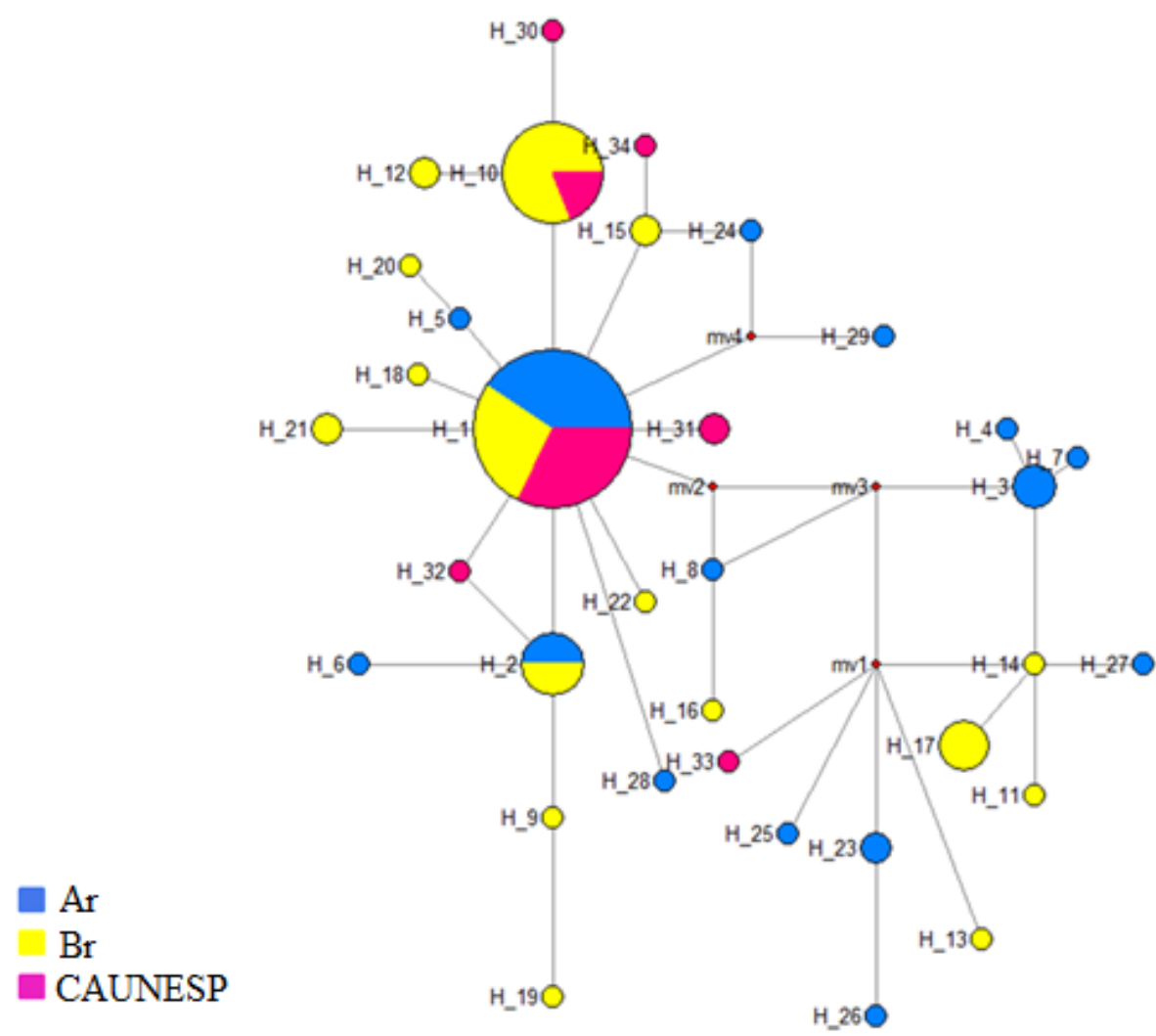

Figure 1 - Network of haplotypes in relation to haplotype flow among fish farms. The size of the circle is proportional to the haplotype frequency. Ar is fish farms from Argentina, $\mathrm{Br}$ is fish farms from Brazil, and CAUNESP from the breeding nucleus.

Ar1, Ar3 and Br1 ought to introduce/replace new breeders with different genetic background, particularly to avoid inbreeding depression that compromises the foundation of hatchery stocks when initiating breeding programs (Duncan et al., 2013; Naish et al., 2013).

The data of the genetic structure indicated the existence of low gene flow among the different stocks of fish farms in Brazil and Argentina. This pattern is expected for the present populations, as the broodstocks are geographically isolated and producers frequently do not exchange breeders among the fish farms, similar what was already detected in a closely related species Piaractus brachypomus by microsatellites (Jorge et al., 2018). In contrast, Mastrochirico-Filho et al. (2019a) demonstrated low differentiation between different farmed stocks from Brazil, which could be attributed to stock foundation based on breeders sharing among fish farms, and/ or stock foundation in the fish farms based on the capture of wild breeders, which are characterized as belonging to a panmictic unit due to the lack of genetic structure in natural populations (Iervolino et al., 2010), particularly because pacu have high gene flow capacity due to their migratory behavior in the wild.

The genetic results of this study generated an improved knowledge of the mitochondrial profile of pacu commercial broodstocks in Brazil and Argentina, which provides a framework for the development of management programs and genetic improvement of this species in aquaculture. In addition, in terms of the genetic composition of the breeding program, the base population showed moderated levels of genetic variability compatible with the wild stocks (high haplotypic and nucleotide diversity), which would reduce the problems related from narrowing the genetic base or loss of genetic potential over the various generations of selection.

\section{Acknowledgments}

This work was supported by São Paulo Research Foundation (FAPESP grant FAPESP 2014/03772-7 and 15/14185-8), National Council for Scientific and Technological Development (CNPq grant 311559/2018-2, 446779/2014-8), and Coordenação de Aperfeiçoamento de Pessoal de Nível Superior - Brasil (CAPES - Finance Code 001).

\section{Conflict of Interest}

The authors declare that there is no conflict of interest that could be perceived as prejudicial to the impartiality of the reported research.

\section{Author Contributions}

MVF and DTH conceived and the study, MVF, RBA, MEH, VAMF and FP conducted the experiments, MVF, FP, GV, FFM and FPF analyzed the data, MVF and DTH wrote the manuscript. All authors read and approved the final version.

\section{References}

Aquadro CF and Greenberg BD (1983) Human mitochondrial DNA variation and evolution Analysis of nucleotide sequences from seven individuals. Genetics 3:287-312.

Brown JR, Beckenbach AT and Smith MJ (1993) Intraespecific DNA sequence variation of the mitochondrial control region of white sturgeon (Acipenser transmontanus). Mol Biol Evol 2:326-341. 
Charlesworth D and Willis JH (2009) The genetics of inbreeding depression. Nat Rev Genet 10:783-96.

Duncan AJ, Teufel N, Mekonnen K and Singh VK (2013) Dairy intensification in developing countries: effects of market quality on farm-level feeding and breeding practices. Animal 7:2054-2062.

Excoffier L, Laval G and Schneider S (2007) ARLEQUIN version 3.01. an integrated software package for population genetics data analysis. Evol Bioinform Online 1:47-50

Excoffier L, Laurent PE, Smouse PE and Quattro JM (1992) Analysis of molecular variance inferred from metric distances among DNA haplotypes: application to human mitochondrial DNA restriction data. Genetics 131(2):479-491.

FAO (2010). The State of World Fisheries and Aquaculture 2010. FAO, Rome.

Flores Nava A (2007) Aquaculture seed resources in Latin America: A regional synthesis. In: Bondad Reantaso MG (ed) FAO fisheries technical paper. Assessment of freshwater fish resources for sustainable aquaculture. FAO, Rome.

Freitas MV, Lieschen VGL, Ariede RB, Agudelo JFG, Oliveira Neto RR, Borges CHS, Mastrochirico-Filho VA, Garcia Neto BF, Carvalheiro R and Hashimoto DT (2020) Genotype by environment interaction and genetic parameters for growth traits in the Neotropical fish pacu (Piaractus mesopotamicus). Aquaculture 530:735933.

Gjedrem T and Baranski M (2010) Selective breeding in aquaculture: An introduction. Springer, Netherlands.

Hall TA (1999) BioEdit: a user-friendly biological sequence alignment editor and analysis program for Windows 95/98/NT. Nucleic Acids Symp Ser 41:95-98

Honglang H (2007) Freshwater fish seed resources in China. In: Bondad Reantaso, MG (ed) FAO fisheries technical paper. Assessment of freshwater fish seed resources for sustainable aquaculture. FAO, Rome, pp 628.

IBGE - Instituto Brasileiro de Geografia e Estatística (2015). Produção da Pecuária Municipal. IBGE, Rio de Janeiro, vol. 43.

Iervolino F, Resender EK and Hilsdorf AWS (2010) The lack of genetic differentiation of pacu (Piaractus mesopotamicus) populations in the Upper Paraguay Basin revealed by the mitochondrial DNA D-loop region: Implications for fishery management. Fish Res 101:27-31.

Jorge PH, Matrochirico-Filho VA, Hata ME, Mendes NJ, Ariede RB, Freitas MV, Vera M, Porto-Foresti F and Hashimoto DT (2018) Genetic characterization of the fish Piaractus brachypomus by microsatellites derived from transcriptome sequencing. Front Genet 9:46.

Librado P and Rozas J (2009) DnaSP v.5: A software for comprehensive analysis of DNA polymorphism data. Bioinform 25:1451-1452.

Lin Y, Gao Z and Zhan A (2015) Introduction and use of nonnative species for aquaculture in China: status, risks and management solutions. Rev Aquac 7:28-58.

Mastrochirico-Filho VA, Del Pazo F, Hata ME, Villanova GV, Foresti F, Vera M, Martínez P, Porto-Foresti F and Hashimoto DT (2019a) Assessing genetic diversity for a pre-breeding program in Piaractus mesopotamicus by SNPs and SSRs. Genes 10:668
Mastrochirico-Filho VA, Ariede RB, Freitas MV, Lira LVG, Agudelo JFG, Pilarski F, Reis RV Neto, Yáñez JM, Hashimoto DT (2019b) Genetic parameters for resistance to Aeromonas hydrophila in the Neotropical fish pacu (Piaractus mesopotamicus). Aquaculture 513: 734442.

Melo DC, Oliveira DAA, Ribeiro LP, Teixeira CD, Sousa AB, Coelho EGA, Crepaldi DV and Teixeira EA (2006) Caracterização genética de seis plantéis comerciais de tilápia (Oreochromis) utilizando marcadores microssatélites. Arq Bras Med Vet Zootec 58:87-93.

Meyer A (1993) Evolution of mitochondrial DNA in fishes. In: Mommsen TP and Hochachka P (eds). Biochemistry and molecular biology of fishes. Elsevier Science, Amsterdam, pp 1-39.

Naish KA, Seamons TR, Dauer MB, Hauser L and Quinn TP (2013) Relationship between effective population size, inbreeding and adult fitness-related traits in a steelhead (Oncorhynchus mykiss) population released in the wild. Mol Ecol 22:1295-1309.

Panné Huidobro S (2015) Producción por Acuicultura en Argentina en el 2015. Informe de la Dirección de Acuicultura Dirección Nacional de Planificación Pesquera Subsecretaría de Pesca y Acuicultura Ministerio de Agroindustria, https://www.magyp. gob.ar/sitio/areas/acuicultura/estadisticas/_archivos//000000 Producci\%C3\%B3n $/ 160526$ Producci $\% \mathrm{C} 3 \% \mathrm{~B} 3 \mathrm{n} \% 20$ por $\% 20$ Acuicultura $\% 20 \mathrm{en} \% 20$ Argentina $\% 20$ durante $\% 20 \mathrm{el} \% 20$ a\%C3\%B10\%202015.pdf

Petrere Jr M (1989) River fisheries in Brazil: A review. Reg River Res Mgmt 4:1-16.

Schenone NF, Vackova L, and Cirelli AF (2011) Fish-farming water quality and environmental concerns in Argentina: a regional approach. Aquac Int 19:855-863.

Thompson JD, Higgins DG and Gibson TJ (1994) CLUSTAL W: improving the sensitivity of progressive multiple sequence alignment through sequence weighting, position specific gap penalties and weight matrix choice. Nucleic Acids Res 22:4673-4680.

Valladão GMR, Gallani SU and Pilarski F (2018) South American fish for continental aquaculture. Rev Aquacult 10:351-369.

Wright S (1965) The interpretation of population structure by F-statistics with special regard to systems of mating. Evolution 395-420.

Wright S (1951) The genetical structure of populations. Ann. Eugenics. 15:323-354

Yosefian M and Nejati A (2008) Inbreeding depression by family matching in rainbow trout (Oncorhynchus mykiss). J Fish Aquat Sci 3:384-391.

Associate Editor: Vera Maria Fonseca de Almeida e Val

License information: This is an open-access article distributed under the terms of the Creative Commons Attribution License (type CC-BY), which permits unrestricted use, distribution and reproduction in any medium, provided the original article is properly cited. 